\title{
Savunma Harcamaları İle Ekonomik Büyüme Arasındaki Illişkinin İncelenmesi: Türkiye İçin Bir Fourier Eşbütünleşme Testi Uygulamast
}

\author{
Analysing The Relationship Between Defense Expenditures And Economic Growth: \\ An Application of Fourier Cointegration Test for Turkey
}

Mustafa Orhan ÖZER*

$\ddot{O} Z$

Savunma harcamaları ile ekonomik büyüme arasındaki ilişki genellikle Benoit hipotezi çerçevesinde ele alınmaktadır. Benoit hipotezine göre savunma harcamalarında meydana gelen artış ekonomik büyümeyi pozitif yönde etkilemektedir. Bu çalışmada, Türkiye'de 1960-2017 dönemi için savunma harcamaları ve ekonomik büyüme arasındaki ilişki Fourier yaklaşımı ile analiz edilmiştir. Değişkenlerin dură̆anlık durumları Fourier ADF birim kök testi ile sınanmış ve düzeyde dură̆an olmadıkları, birinci farkı alındıktan sonra durağan hale geldikleri anlaşılmıştır. Değişkenler arasındaki uzun dönemli ilişkinin varlığını araştırmak amacıyla Fourier ADL eşbütünleşme testi uygulanmış ve savunma harcamaları ile ekonomik büyüme arasında uzun dönemli ilişki olmadığ tespit edilmiştir. Son olarak, Toda-Yamamoto nedensellik testi uygulanmış ve değişkenler arasında nedensellik ilişkisi olmadı̆̆ı görülmüştür. Yapılan analizler Türkiye’de Benoit hipotezinin geçerli olmadığını göstermektedir.

ANAHTAR KELIMELER

Benoit Hipotezi, Ekonomik Büyüme, Fourier Yaklaşımı, Savunma Harcamaları

\begin{abstract}
The relationship between defense expenditures and economic growth is generally considered within the framework of the Benoit hypothesis. According to the Benoit hypothesis, increase in the defense expenditures positively affects economic growth. In this study, the relationship between defense expenditures and economic growth in Turkey for the period 1960 2017 was analyzed with the Fourier approach. The stationarity of the variables was examined with the Fourier ADF unit root test. It is understood that the variables are not stationary at the levels but they are stationary at the first differences. The Fourier ADL cointegration test was applied to investigate the existence of the long term relationship between the variables and it was determined that there is no long-run relationship between defense expenditures and economic growth. Finally, Toda-Yamamoto causality test was applied and it was observed that there is no causal relationship between the variables. The analysis show that Benoit hypothesis is not valid in Turkey.
\end{abstract}

\section{KEYWORDS}

Benoit Hypothesis, Economic Growth, Fourier Approach, Defense Expenditures

\begin{tabular}{|c|c|c|}
\hline \multicolumn{2}{|r|}{$\begin{array}{c}\text { Makale Geliş Tarihi / Submission Date } \\
\text { 25.12.2019 }\end{array}$} & $\begin{array}{c}\text { Makale Kabul Tarihi / Date of Acceptance } \\
25.03 .2020\end{array}$ \\
\hline Atıf & $\begin{array}{l}\text { Özer, M.O. (2020). Savunma Harcama } \\
\text { Fourier Eşbütünleşme Testi Uygulame } \\
\text { 186-197. }\end{array}$ & $\begin{array}{l}\text { me Arasındaki İlişkinin İncelenmesi: Türkiye İçin Bir } \\
\text { Sosyal Bilimler Meslek Yüksekokulu Dergisi, } 23 \text { (1), }\end{array}$ \\
\hline
\end{tabular}

\footnotetext{
*Dr., mustafaorhanozer@gmail.com, ORCID: 0000-0002-3222-9913
} 


\section{GİRIŞ}

XX. yüzyılın ilk yarısında patlak veren iki dünya savaşı ve ikinci yarısında ağırlığı hissedilen soğuk savaş, dünya üzerinde hemen hemen her ülkede ulusal güvenlik endişelerinin ve savunma harcamalarının artmasına yol açmıştır. 1990'lı yılların başında soğuk savaşın sona ermesiyle birlikte savunma harcamaları dünya çapında hızlı bir şekilde düşüş göstermesine rağmen, bazı ülkelerde bu harcamaların artmaya devam ettiği görülmüştür (Dunne ve Nikolaidou, 2001: 48).

Nüfus artışı, iç karışıklık, savaş, terör, komşu ülkelerin düşmanca tavır sergilemesi ve silahlanmaya hız vermesi gibi nedenlerin savunma harcamalarının artmasında etkili olduğu bilinmektedir (Kesgingöz ve Olcay, 2016: 601). Türkiye'nin yakın tarihine bakıldığında, 1974 Kıbrıs Barış Harekatı, 1980-1988 Irak-İran Savaş1 ve 1996 Kardak krizinin savunma harcamalarının GSYİH'ye oranının ani bir şekilde artmasına neden olduğu dikkat çekmektedir. Son yıllarda Karadeniz, Akdeniz ve Ege sularında ortaya çıkan uluslararası gerginlikler, komşu ülkelerde yaşanan iç karışıklıklar ve bölgede çeşitli eylemlerde bulunan terör örgütleri de göz önünde tutulduğunda, Türkiye'nin yüksek düzeyde savunma harcamalarında bulunmasının tercihten ziyade zorunluluk olduğu açıktır. Buna rağmen, Türkiye'de savunma harcamaları ile ekonomik büyüme arasındaki uzun dönemli ilişkinin incelenmesi, savunma harcamalarının iktisadi bir politika aracı olarak kullanılıp kullanılamayacağını açıklığa kavuşturmak adına büyük önem taşımaktadır.

Benoit (1978), çalışmasında aralarında Türkiye'nin de bulunduğu 44 gelişmekte olan ülkede 1950-1965 döneminde büyüme oranı, yatırım oranı, diğer ülkeler tarafindan yapılan yardımlar ve bazı diğer değişkenleri de kullanarak savunma harcamaları ile ekonomik büyüme arasındaki ilişkiyi korelasyon ve regresyon analizi ile araştırmıştır. Analiz sonucunda savunma harcamalarının yüksek olduğu ülkelerde büyüme oranının yüksek; düşük olduğu ülkelerde ise büyüme oranının da düşük olduğu tespit edilmiştir. İlerleyen yıllarda bu konuda çok sayıda çalışma yapılmış ve gelişmekte olan ülkelerde savunma harcamalarının büyüme üzerindeki olumlu etkisi Benoit hipotezi olarak anılmaya başlanmıştır.

Savunma harcamalarının ekonomik büyüme üzerindeki etkileri konusunda talep yanlı Keynesyen yaklaşım ve arz yanlı Neoklasik yaklaşım olmak üzere iki farklı yaklaşımdan söz edilebilir. Keynesyen yaklaşıma göre; talebin yetersiz olması durumunda savunma harcamaları tıpk1 bir maliye politikas1 aracı gibi toplam talebi teşvik edecek şekilde kullanılabilmektedir. Burada, harcama çarpanının büyüklüğü ekonomik büyümede meydana gelecek artışta oldukça belirleyicidir. Diğer taraftan, kamu harcamalarındaki artışın; tüketim, yatırım veya net ihracatta azalmasına yol açan dışlama etkisi de büyüme oranı üzerinde etkili olmaktadır. Dışlama etkisinin olmadığ 1 durumda büyümedeki artış, tamamen kamu harcamalarındaki artış ve çarpan tarafından belirlenirken, kısmi dışlama etkisi olduğu durumda büyümedeki artış beklenenden daha az olmaktadır. Tam dışlama etkisi olması halinde ise iktisadi büyümede herhangi bir artış görülmemektedir (Gerace, 2002: 2).

Neoklasik yaklaşıma göre; savunma harcamalarında meydana gelen artış, hem daha fazla vergi yüküne, hem de tasarruf ve yatırım oranlarının azalmasına yol açarak ekonomik büyümeyi yavaşlatmaktadır (Faini ve di ̆. ., 1984: 487). Savunma harcamalarının artması, kamu harcamalarının artmasına ve dışlama etkisi ile özel yatıımların azalmasına neden olmaktadır. Savunma harcamalarının vergi artışı ile finanse edilmesi durumunda özel tasarruflar azalmakta ve faiz oranı yükselmektedir. Savunma harcamalarının borçlanma yolu ile finanse edilmesi durumunda ise yurtiçi fon arzı ve yurtiçi fon talebi yeniden dengeye gelene kadar faiz oranı yükselmektedir. Her iki durumda da artan faiz oranı özel yatırımların dışlanmasına, toplam arzın, GSYİH'nin ve istihdamın azalmasına neden olmaktadır (Ajmair ve diğ., 2018: 41).

Savunma harcamaları ile ekonomik büyüme arasındaki ilişkinin doğasına göre dört farklı hipotezin varlığından bahsetmek mümkündür. Birinci hipoteze göre savunma harcamalarından büyümeye doğru tek yönlü nedensellik ilişkisi bulunmaktadır. Savunma harcamalarındaki artışın büyüme oranını ne yönde etkileyeceği Keynesyen ve Neoklasik yaklaşıma göre farkl11ık göstermektedir. İkinci hipoteze göre büyümeden savunma harcamalarına doğru tek yönlü nedensellik ilişkisi bulunmaktadır. Üçüncü hipotez, değişkenler arasında karşılıklı nedensellik ilişkisi olduğunu iddia etmektedir. Buna göre büyüme oranında meydana gelen azalma savunma harcamalarını; savunma harcamalarındaki artışı sınırlayıcı nitelikteki politikalar da büyüme oranını olumsuz yönde etkilemektedir. Dördüncü hipoteze göre ise değişkenler arasında herhangi bir nedensellik ilişkisi bulunmamaktadır. Bu dört hipotezin farklı politik sonuçları olduğu için, savunma harcamaları ile büyüme arasındaki ilişkinin incelenmesi, iktisadi açıdan uygun askeri harcama stratejilerinin ve politikaların belirlenmesi konusunda oldukça önemlidir (Pan ve diğ., 2015: 443-444).

Çalışmada Türkiye'de 1960-2017 yılları arasında savunma harcamaları ile ekonomik büyüme arasındaki iliş̧ki incelenmektedir. Benoit hipotezinin geçerliliğini sınayan ampirik çalışmalara bakıldığında çeşitli yöntemlerin kullanıldığı görülmektedir. Bu çalışmada önceki çalışmalardan farklı olarak Benoit hipotezinin geçerliliği Fourier yaklaşımı ile test edilmektedir. İlerleyen bölümlerde sırasıyla konu ile ilgili literatüre yer 
verilecek, kullanılan ekonometrik yöntem aktarılacak, ampirik bulgular değerlendirilecek ve çalışma sonuç bölümüyle sonlandırılacaktır.

\section{LITERATÜR ARAŞTIRMASI}

Literatürde Benoit hipotezinin geçerliliğini sınayan çok sayıda çalışma bulunmaktadır. Çeşitli ülkeler için savunma harcamaları ile ekonomik büyüme arasındaki ilişkiyi inceleyen çalışmalar aşağıdaki gibidir:

Lee ve Chen (2007), çalışmalarında Tayvan'da 1960-2002 dönemine ait y1llık verilerle savunma harcamaları ile ekonomik büyüme arasındaki ilişkiyi Hansen eşik regresyon yöntemi ile analiz etmişlerdir. Analiz sonucunda, yalnızca savunma harcamalarının düşük olması durumda Benoit hipotezinin geçerli olduğu sonucuna ulaşılmıştır.

Ateşoğlu (2009), çalışmasında 1948 yılının ilk çeyreği ile 2007 yılının ilk çeyreği dönemini kapsayan üç aylık verilerle, $\mathrm{ABD}$ için savunma harcamalarının toplam çıktı üzerindeki etkisini Johansen eşbütünleşme testi ile analiz etmiştir. Elde edilen bulgular, savunma harcamalarının toplam çıktıyı pozitif yönde etkilediğini ortaya koymaktadır.

Wijeweera ve Webb (2009), çalışmalarında Sri Lanka'da 1976-2007 dönemine ait yıllık verilerle savunma harcamaları ile ekonomik büyüme arasındaki ilişkiyi VAR analizi ile araştırmışlardır. Çalışmada savunma harcamalarındaki artışın büyümeyi pozitif yönde etkilediği, ancak bu etkinin oldukça sınırlı olduğu sonucuna ulaşılmıştır.

Pradhan (2010), çalışmasında Çin, Hindistan, Nepal ve Pakistan'da 1988-2007 dönemine ait yıllık verilerle savunma harcamaları ile ekonomik büyüme arasındaki ilişkiyi Johansen eşbütünleşme, Pedroni eşbütünleşme ve Granger nedensellik testleri ile incelemiştir. Çalışmada, bütün ülkeler için değişkenler arasında uzun dönemli ilişki bulunmuştur. Çin ve Nepal'de savunma harcamalarından büyümeye doğru tek yönlü nedensellik ilişkisi olduğu tespit edilmiştir. Ayrıca söz konusu ülkelerden herhangi birinin savunma harcamalarında meydana gelen değişimin, diğer ülkelerin savunma harcamaları üzerinde de etkili olduğu bulgusuna ulaşılmıştır.

Feridun ve diğ. (2011), çalışmalarında Kuzey Kıbrıs Türk Cumhuriyeti'nde 1977-2007 dönemine ait yıllık verilerle savunma harcamaları ile ekonomik büyüme arasındaki ilişkiyi ARDL sınır testi yaklaşımı ve Granger nedensellik testi ile analiz etmişlerdir. Ulaşılan sonuçlar, savunma harcamalarının büyümeyi pozitif yönde etkilediğine işaret etmektedir.

Tiwari ve Shahbaz (2013), çalışmalarında Hindistan'da 1971-2010 dönemine ait yıllık verilerle savunma harcamaları ile ekonomik büyüme arasındaki ilişkiyi ARDL sınır testi yaklaşımı ve Granger nedensellik testi ile incelemişlerdir. Savunma harcamalarının büyüme üzerindeki etkisinin pozitif olduğu, ancak belirli bir düzeyden sonra bu etkinin negatif hale geldiği tespit edilmiştir. Ayrıca değişkenler arasında çift yönlü nedensellik ilişkisi bulunmuştur.

Chen (2014), çalışmasında Çin'de 1978-2013 dönemine ait yıllık verilerle savunma harcamaları ile ekonomik büyüme arasındaki ilişkiyi Johansen eşbütünleşme ve Granger nedensellik testleri ile analiz etmiştir. Çalışmada değişkenler arasında uzun dönemli ilişki olduğu ve büyümeden savunma harcamalarına doğru nedensellik ilişkisi olduğu tespit edilmiştir.

Khalid ve Alsalim (2015), çalışmalarında ABD'de 1970-2011 dönemine ait yıllık verilerle savunma harcamaları ile ekonomik büyüme arasındaki ilişkiyi ARDL sınır testi yaklaşımı ile araştırmışlardır. Analiz sonucunda savunma harcamalarının büyümeyi negatif yönde etkilediği görülmüştür.

Jalil ve diğ. (2016), çalışmalarında Hindistan ve Pakistan'da 1960-2013 dönemine ait yıllık verilerle savunma harcamaları ile ekonomik büyüme arasındaki ilişkiyi ARDL sınır testi yaklaşımı, Gregory-Hansen eşbütünleşme ve Granger nedensellik testleri ile incelemişlerdir. Değişkenler arasındaki ilişkinin pozitif olduğu, ancak belirli bir düzeyden sonra bu ilişkinin negatif hale geldiği görülmüştür. Ayrıca savunma harcamalarının büyümenin nedeni olduğu tespit edilmiştir.

Kovacevic ve Smiljanic (2017), çalışmalarında Hırvatistan'da 1995-2014 dönemine ait y1llık verilerle savunma harcamaları ile ekonomik büyüme arasındaki ilişkiyi Johansen eşbütünleşme ve Toda-Yamamoto nedensellik testleri ile araştırmışlardır. Analiz sonucunda kısa ve uzun dönemde değişkenler arasında herhangi bir ilişki bulunmamıştır.

Turan ve diğg. (2018), çalışmalarında 12 düşük ve 29 yüksek gelirli ülkede 1988-2016 dönemine ait yıllık verilerle savunma harcamaları ile ekonomik büyüme arasındaki ilişkiyi Westerlund panel eşbütünleşme ve Dumitrescu-Hurlin panel nedensellik testleri ile araştırmışlardır. Panel eşbütünleşme testine göre her iki ülke grubunda da değişkenler arasında uzun dönemli ilişki bulunmaktadır. Panel nedensellik testine göre; yüksek gelirli ülkelerde savunma harcamalarından büyümeye doğru tek yönlü, düşük gelirli ülkelerde ise değişkenler arasında çift yönlü ilişki bulunmaktadır. 
Benoit hipotezinin geçerliliği konusunda Türkiye'yi de kapsayan çalışmalar şu şekilde özetlenebilir:

Gökbunar ve Yanıkkaya (2004), çalışmalarında 29 gelişmiş ve aralarında Türkiye'nin de bulunduğu 85 gelişmekte olan ülkede 1980-1997 dönemine ait yıllık verilerle savunma harcamalarının ekonomik büyüme üzerindeki etkisini regresyon yöntemi ile analiz etmişlerdir. Analiz sonucunda gelişmekte olan ülkelerde savunma harcamalarının büyümeyi pozitif yönde etkilediği, gelişmiş ülkelerde ise değişkenler arasında ilişki olmadığı tespit edilmiştir.

Halıcıoğlu (2004), çalışmasında Türkiye'de 1950-2002 dönemine ait yıllık verilerle savunma harcamaları ile ekonomik büyüme arasındaki ilişkiyi Johansen-Juselius eşbütünleşme testi ile araştırmıştır. Analiz sonucunda savunma harcamalarının büyümeyi pozitif yönde etkilediği tespit edilmiştir.

Karagöl ve Palaz (2004), çalışmalarında Türkiye'de 1955-2000 dönemine ait yıllık verilerle savunma harcamaları ile ekonomik büyüme arasındaki ilişkiyi Johansen-Juselius eşbütünleşme ve Granger nedensellik testleri ile analiz etmiş̧erdir. Çalışmada, değişkenler arasında uzun dönemli ilişki olduğu ve savunma harcamalarının büyümeyi negatif yönde etkilediği tespit edilmiştir.

Yıldırım ve diğ. (2005), çalışmalarında 4 yüksek gelirli, 3 orta gelirli ve aralarında Türkiye'nin de bulunduğu 6 düşük gelirli Ortadoğu ülkesinde 1989-1999 dönemine ait yıllık verilerle savunma harcamaları ile ekonomik büyüme arasındaki ilişkiyi panel veri analizi ile incelemişlerdir. Ulaşılan sonuçlar, savunma harcamalarının büyümeyi pozitif yönde etkilediğini ortaya koymaktadır.

Görkem ve Işık (2008), çalışmalarında Türkiye'de 1968-2016 dönemine ait yıllık verilerle savunma harcamaları ile ekonomik büyüme arasındaki ilişkiyi Granger nedensellik testi ile analiz etmişlerdir. Çalışmada değişkenler arasında herhangi bir ilişki bulunmamıştır.

Yılancı ve Özcan (2010), çalışmalarında Türkiye'de 1950-2006 dönemine ait yıllık verilerle savunma harcamaları ile GSMH arasındaki ilişkiyi Gregory-Hansen eşbütünleşme ve Toda-Yamamoto nedensellik testleri ile araştırmışlardır. Çalışmada değişkenler arasında uzun dönemli ilişki bulunamamış, fakat GSMH'den savunma harcamalarına doğru tek yönlü nedensellik ilişkisi olduğu tespit edilmiştir.

Alptekin (2012), çalışmasında aralarında Türkiye'nin de bulunduğu 24 OECD ülkesinde 1991-2008 dönemine ait yıllık verilerle savunma harcamaları ile ekonomik büyüme arasındaki ilişkiyi panel veri yöntemi ile araştırmıştır. Ulaşılan sonuçlar, savunma harcamalarının büyümeyi negatif yönde etkilediğine işaret etmektedir.

Başar ve Künü (2012), çalışmalarında aralarında Türkiye'nin de bulunduğu 36 ülkede 1997-2004 dönemine ait yıllık verilerle savunma harcamalarının ekonomik büyüme üzerindeki etkisini sabit etkili ve tesadüfi etkili modellerle araştırmışlardır. Çalışmada, savunma harcamalarında meydana gelen artışın büyüme oranında azalmaya yol açtı̆̆ sonucuna ulaşılmıştır.

Soyyiğit Kaya (2013), çalışmasında Türkiye'de 1970-2010 dönemine ait y1llık verilerle savunma harcamaları ile GSMH arasındaki ilişkiyi Johansen eşbütünleşme, Granger nedensellik ve Toda-Yamamoto nedensellik testleri ile araştırmıştır. Eşbütünleşme testine göre değişkenler uzun dönemde ilişkisizdir. Granger nedensellik testine göre değişkenler arasında ilişki bulunmamaktadır. Toda-Yamamoto nedensellik testine göre ise savunma harcamaları büyümenin nedenidir.

İpek (2014), çalışmasında Türkiye ve İsrail'de 1980-2012 dönemine ait yıllık verilerle savunma harcamaları ile ekonomik büyüme arasındaki ilişkiyi ARDL sınır testi yaklaşımı ile analiz etmiştir. Çalışmada Türkiye için değişkenler arasında ilişki bulunmadığı, İsrail için ise savunma harcamalarının büyümeyi negatif yönde etkilediği sonucuna ulaşılmıştır.

Korkmaz (2015), çalışmasında aralarında Türkiye'nin de bulunduğu 10 Akdeniz ülkesinde 2005-2012 dönemine ait yıllık verilerle savunma harcamaları ile ekonomik büyüme arasındaki ilişkiyi panel veri analizi ile araştırmıştır. Elde edilen bulgular, savunma harcamalarının büyümeyi negatif yönde etkilediğini ortaya koymaktadır.

Destek (2016), çalışmasında aralarında Türkiye'nin de bulunduğu 14 NATO ülkesinde 1988-2014 dönemine ait yıllık verilerle savunma harcamaları ile ekonomik büyüme arasındaki ilişkiyi yatay kesit bağımlılığını dikkate alan panel veri yöntemleri, Dumitrescu-Hurlin panel nedensellik yöntemi ve ardışık panel nedensellik yöntemi ile analiz etmiştir. Çalışmada ülkeler bazında farklı sonuçlara ulaşılsa da, Türkiye için büyümeden savunma harcamalarına doğru tek yönlü nedensellik ilişkisi olduğu tespit edilmiştir.

Kesgingöz ve Olcay (2016), çalışmalarında aralarında Türkiye'nin de bulunduğu 8 Ortadoğu ülkesinde 1991-2014 dönemine ait yıllık verilerle savunma harcamaları ile ekonomik büyüme arasındaki ilişkiyi panel veri analizi yöntemi ile araştırmışlardır. Analiz sonucunda savunma harcamalarının genel olarak büyümenin azalmasına yol açtığını tespit etmişlerdir. 
Manamperi (2016), çalışmasında Türkiye ve Yunanistan'da 1970-2013 dönemine ait y1llık verilerle savunma harcamaları ile ekonomik büyüme arasındaki ilişkiyi ARDL sınır testi yaklaşımı ile araştırmıştır. Çalışmada Yunanistan için değişkenler arasında herhangi bir ilişki bulunamazken, Türkiye için hem kısa hem de uzun dönemde savunma harcamalarının ekonomik büyümeyi negatif yönde etkilediği tespit edilmiştir.

Paparas ve diğg. (2016), çalışmalarında Türkiye ve Yunanistan'da 1957-2013 dönemine ait yıllık verilerle savunma harcamaları ile ekonomik büyüme arasındaki ilişkiyi Engle-Granger eşbütünleşme, Johansen eşbütünleşme ve Granger nedensellik testleri ile araştırmışlardır. Engle-Granger eşbütünleşme testinden elde edilen sonuçlara göre, her iki ülkede de savunma harcamalarının büyüme üzerinde negatif etki yarattığı tespit edilmiştir. Uygulanan Johansen eşbütünleşme testine göre ise, Yunanistan'da savunma harcamaları ile büyüme arasında uzun dönemli ilişki bulunurken, Türkiye'de değişkenler arasında uzun dönemli ilişki bulunamamıştır. Ayrıca iki ülkede de savunma harcamalarından büyümeye doğru nedensellik ilişkisi olduğu bulgusuna ulaşılmıştır.

Canbay ve Mercan (2017), çalışmalarında Türkiye'de 1986-2016 dönemine ait y1llık verilerle savunma harcamaları ile ekonomik büyüme arasındaki ilişkiyi Johansen eşbütünleşme testi ile incelemişlerdir. Analiz sonucunda, savunma harcamalarında meydana gelen artışı büyümeyi kısa dönemde negatif, uzun dönemde ise pozitif yönde etkilediği bulgusuna ulaşmışlardır.

Eğri ve diğg. (2017), çalışmalarında aralarında Türkiye'nin de bulunduğu 5 Ortadoğu ülkesinde 1970-2012 dönemine ait yıllık verilerle savunma harcamaları ile ekonomik büyüme arasındaki ilişkiyi panel veri analizi yöntemi ile araştırmışlardır. Çalışmada savunma harcamalarının büyüme üzerinde negatif etki yarattığı sonucuna ulaşılmıştır.

Korkmaz ve Bilgin (2017), çalışmalarında ABD ve Türkiye'de 1961-2015 dönemine ait yıllık verilerle savunma harcamaları ile ekonomik büyüme arasındaki ilişkiyi Johansen-Juselius eşbütünleşme ve Granger nedensellik testleri ile analiz etmişlerdir. Çalışmada Türkiye için savunma harcamaları ile büyüme arasında çift yönlü nedensellik ilişkisi olduğu tespit edilirken, ABD için değişkenler arasında nedensellik ilişkisi olmadığı ifade edilmiştir.

Topal (2018), çalışmasında Türkiye'de 1960-2016 dönemine ait yıllık verilerle savunma harcamaları ile ekonomik büyüme arasındaki ilişkiyi çeşitli eşbütünleşme testleri ile incelemiştir. Bayer-Hanck eşbütünleşme testine göre savunma harcamaları büyümeyi negatif yönde etkilerken, Maki eşbütünleşme testine göre değişkenler arasında ilişki bulunmamaktadır.

Şit (2018), çalışmasında Türkiye'de 1980-2016 dönemine ait yıllık verilerle savunma harcamalarının ekonomik büyüme, enflasyon, cari denge, ithalat ve istihdam üzerindeki etkilerini Granger ve Toda-Yamamoto nedensellik testleri ile araştırmıştır. Analiz sonucunda savunma harcamalarının büyüme üzerinde etkili olmadığ bulgusuna ulaşılmıştır.

Yıldız ve Akbulut Yıldız (2019), çalışmalarında aralarında Türkiye'nin de bulunduğu 5 Ortadoğu ülkesinde 1990-2015 dönemine ait yıllık verilerle savunma harcamaları ile ekonomik büyüme arasındaki ilişkiyi Bootstrap panel nedensellik testi ile araştırmışlardır. Çalışmada büyümenin savunma harcamalarının nedeni olduğu sonucuna ulaşılmıştır.

\section{EKONOMETRIK YÖNTEM}

Bu çalışmada, savunma harcamaları ile ekonomik büyüme arasındaki ilişki Fourier yaklaşımı çerçevesinde analiz edilmiştir. Fourier yaklaşımına dayanan birim kök ve eşbütünleşme testlerinde, serilerde meydana gelen sert kırılmaların yanı sıra yumuşak geçişli kırılmalar da kolaylıkla tespit edilebilmektedir. Dolayısıyla bu testler, serilerin etkisi altında bulunduğu yapısal kırılmaların sayısı, konumu ve formundan bağımsız bir şekilde daima güçlü sonuçlar vermektedir (Yılanc1, 2017: 56). Çalışmada değişkenlerin durağanlıklarını test etmek için Christopoulos ve Ledesma (2010) tarafından geliştirilen FADF birim kök testi, değişkenler arasındaki uzun dönemli ilişkiyi test etmek amacıyla da Banerjee ve diğ. (2017) tarafından geliştirilen FADL eşbütünleşme testi kullanılmıştır.

\subsection{Fourier ADF Birim Kök Testi}

FADF birim kök testinde aşağıdaki model dikkate alınmaktadır (Christopoulos ve Ledesma, 2010: 1081):

$y_{t}=\delta_{0}+\delta_{1} \sin \left(\frac{2 \pi k t}{T}\right)+\delta_{2} \cos \left(\frac{2 \pi k t}{T}\right)+v_{t}$

Burada $\mathrm{t}$ trend terimini, $\mathrm{T}$ örneklem büyüklüğünü, $\mathrm{k}$ frekans değerini göstermektedir. $\pi=3.1415$ olarak alınmaktadır. Temel hipotez aşağıdaki gibidir:

$H_{0}: v_{t}=\mu_{t}, \quad \mu_{t}=\mu_{t-1}+h_{t}$ 
Burada $h_{t}$ 'nin sıfir ortalama ile durağan süreç olduğu varsayılmaktadır. Test istatistiklerinin üç adımdan oluşan bir yol izlenerek hesaplanması önerilmektedir:

İlk adımda 6'dan küçük pozitif tam sayılar arasından optimum $\mathrm{k}$ değeri bulunmaktadır. Bu değer kalıntı kareler toplamını (KKT) minimize etmektedir. Daha sonra modelin kalıntıları elde edilir:

$\hat{v}_{t}=y_{t}-\left[\hat{\delta}_{0}+\hat{\delta}_{1} \sin \left(\frac{2 \pi k^{*} t}{T}\right)+\hat{\delta}_{2} \cos \left(\frac{2 \pi k^{*} t}{T}\right)\right]$

İkinci adımda kalıntılara birim kök testi uygulanır:

$\Delta v_{t}=\alpha_{1} v_{t-1}+\sum_{j=1}^{p} \beta_{j} \Delta v_{t-j}+u_{t}$

(4) numaralı modelin kalıntılara uygulanması ile FADF testi yapılmış olmaktadır. FADF birim kök testine ait temel ve alternatif hipotezler (5) ve (6) numaralı denklemlerde gösterilmektedir:

$\mathrm{H}_{0}: \alpha_{1}=0$

$\mathrm{H}_{1}: \alpha_{1}<0$

Üçüncü adımda F testi kullanılarak trigonometrik terimlerin anlamlı olup olmadıklarına bakılmaktadır:

$\mathrm{H}_{0}: \delta_{1}=\delta_{2}=0$

$\mathrm{H}_{1}: \delta_{1} \neq \delta_{2} \neq 0$

F testi için gerekli olan kritik değerler Becker ve diğ. (2006) tarafından hesaplanmıştır. Trigonometrik terimlerin anlamsız olduğunu ifade eden temel hipotezin reddedilememesi halinde, FADF birim kök testi yerine ADF birim kök testi uygulanmaktadır.

\subsection{Fourier ADL Eşbütünleşme Testi}

FADL eşbütünleşme testinde aşağıdaki model dikkate alınmaktadır (Banerjee ve diğ., 2017: 116):

$\Delta y_{1 t}=d_{t}+\delta_{1} y_{1, t-1}+\gamma^{\prime} y_{2, t-1}+\varphi^{\prime} \Delta y_{2 t}+\varepsilon_{t}$

$\mathrm{d}_{\mathrm{t}}$ deterministik terim olarak tanımlanmakta ve (10) numaralı denklemde görüldüğü gibi Fourier yaklaşımı kullanılarak ifade edilmektedir:

$d_{t}=\gamma_{0}+\sum_{k=1}^{q} \gamma_{1, k} \sin \left(\frac{2 \pi k t}{T}\right)+\sum_{k=1}^{q} \gamma_{2, k} \cos \left(\frac{2 \pi k t}{T}\right)$

Burada yer alan $\gamma, \varphi, y_{2 t}$ açıklayıcı değişkenlerdir ve $\mathrm{n} \times 1$ parametre vektörlerini ifade etmektedir. $y_{1 t}$ bağımlı değişkeni, $\varepsilon_{t}$ hata terimini göstermektedir. Uygun gecikme sayısının belirlenmesinde Akaike Bilgi Kriteri dikkate alınmaktadır. FADL eşbütünleşme testine ait temel ve alternatif hipotezler (11) ve (12) numaralı denklemlerde görülmektedir (Banerjee ve diğ., 2017: 117):

$\mathrm{H}_{0}: \delta_{1}=0$

$\mathrm{H}_{1}: \delta_{1}<0$

Temel hipotez değişkenler arasında uzun dönemli ilişki olmadığını, alternatif hipotez ise değişkenler arasında uzun dönemli ilişki bulunduğunu göstermektedir. Test istatistiği (13) numaralı denklem yardımı ile elde edilmektedir:

$t_{A D L}^{F}=\frac{\widehat{\delta}_{1}}{s e\left(\widehat{\delta}_{1}\right)}$

Mutlak değerler için, hesaplanan değerin kritik değerden yüksek olması halinde temel hipotez reddedilmektedir. Tersi durumda ise temel hipotez reddedilmemekte ve değişkenler arasında uzun dönemli ilişki bulunmadığı kabul edilmektedir.

\section{VERI SETİ, MODEL VE AMPÍRIKK BULGULAR}

Çalışmada Türkiye'de 1960-2017 dönemine ait yıllık verilerle savunma harcamaları ile ekonomik büyüme arasındaki ilişki Fourier ADL eşbütünleşme testi ile incelenmiştir. Daha tutarlı ve güçlü sonuçlar elde etmek amacıyla, ekonomik büyüme üzerinde etkili olduğu kabul edilen bazı değişkenlerin de modele dahil edilmesine karar verilmiştir. Bu amaçla, Cobb ve Douglas (1928) tarafindan geliştirilen üretim fonksiyonu dikkate alınarak, emek ve sermaye faktörleri de bağımsız değişken olarak modele dahil edilmiştir. Ekonomik 
büyümeyi temsilen World Bank (WB) veri tabanından elde edilen reel gayri safi yurtiçi hasıla, savunma harcamalarını temsilen Stockholm International Peace Research Institute (SIPRI) veri tabanından elde edilen reel askeri harcamalar verileri kullanılmıştır. Emek faktörünü temsil etmesi için kullanılan toplam sivil işgücü ve sermaye faktörünü temsil etmesi için kullanılan reel sermaye stoku verileri ise Federal Reserve Bank of St. Louis (FRED) veri tabanından elde edilmiştir. Bütün seriler doğal logaritmaları alınarak kullanılmışıır.

Çalışmada kullanılan değişkenler ve kısaltmaları şu şekildedir:

$\begin{array}{ll}\text { LNGSYIH } & \text { : Gayri safi yurtiçi hasılanın doğal logaritması } \\ \text { LNAH } & \text { : Askeri harcamaların doğal logaritması } \\ \text { LNL } & \text { : Sivil işgücünün doğal logaritması } \\ \text { LNK } & \text { : Sermaye stokunun doğal logaritması }\end{array}$

Savunma harcamaları ile ekonomik büyüme arasındaki uzun dönemli ilişkiyi test etmek için kullanılan model (14) numaralı denklemde görülmektedir:

$$
\begin{gathered}
\Delta L N G S Y I H_{t}=\delta_{0}+\delta_{1} L N G S Y I H_{t-1}+\delta_{2} L N A H_{t-1}+\delta_{3} L N L_{t-1}+\delta_{4} L N K_{t-1}+\delta_{5} \Delta L N G S Y I H_{t-1}+ \\
\delta_{6} \Delta L N A H_{t-1}+\delta_{7} \Delta L N L_{t-1}+\delta_{8} \Delta L N K_{t-1}+\delta_{9} \sin \left(\frac{2 \pi k t}{T}\right)+\delta_{10} \cos \left(\frac{2 \pi k t}{T}\right)+\varepsilon_{t}
\end{gathered}
$$

Değişkenlerin durağanlık durumlarını incelemek amacıyla ilk olarak sabitli, daha sonra da sabitli ve trendli seçenekleri tercih edilerek FADF ve ADF testleri uygulanmıştır. Uygulanan birim kök testlerine ait sonuçlar Tablo 1 ve Tablo 2'de sunulmuştur.

Tablo 1. FADF ve ADF Birim Kök Testi Sonuçları (Sabit Terimli)

\begin{tabular}{cccccc}
\hline Değişkenler & Min KKT & $\mathbf{k}$ & FADF & ADF & F istatistiği \\
\hline LNGSYIH & 13.697 & 1 & -0.551 & & 34.548 \\
FARKLNGSYIH & 0.079 & 1 & -7.770 & -7.398 & 0.821 \\
LNAH & 11.668 & 1 & -0.925 & & 41.699 \\
FARKLNAH & 0.515 & 3 & -6.385 & -6.102 & 1.859 \\
LNL & 1.452 & 1 & -0.254 & & 41.412 \\
FARKLNL & 0.023 & 3 & -8.646 & -7.414 & 3.925 \\
LNK & 20.648 & 1 & -0.639 & & 33.183 \\
FARKLNK & 0.018 & 3 & -3.572 & & 10.800
\end{tabular}

Not: $\% 5$ anlamlılık düzeyinde kritik değerler FADF birim kök testi için (k=1) -3.85 ve (k=3) -3.06, ADF birim kök testi için -2.91, F testi için
4.929 şeklindedir.

Tablo 1'de sabit terimli birim kök testlerine ait sonuçlar görülmektedir. Öncelikle LNGSYIH, LNAH, LNL ve LNK değiş̧kenlerine seviyelerinde FADF birim kök testi uygulanmış ve dört değişkenin de durağan olmadığ 1 tespit edilmiştir. Daha sonra değişkenlerin birinci farkı alındıktan sonra FADF birim kök testi uygulanmış ancak FARKLNK dışındaki değişkenler için trigonometrik terimlerin anlamsız olduğu görülmüştür. Bunun üzerine, trigonometrik terimlerin anlamsız çıktığı fark serilerine ADF birim kök testi uygulanmış ve değişkenlerin birim köklü olmadıkları anlaşılmıştır.

Tablo 2. FADF ve ADF Birim Kök Testi Sonuçları (Sabit Terimli ve Trendli)

\begin{tabular}{cccccc}
\hline Değişkenler & Min KKT & k & FADF & ADF & F istatistiği \\
\hline LNGSYIH & 0.103 & 1 & -3.664 & & 5364.970 \\
FARKLNGSYIH & 0.079 & 1 & -7.748 & -7.338 & 0.567 \\
LNAH & 1.069 & 1 & -3.452 & & 476.138 \\
FARKLNAH & 0.476 & 3 & -7.129 & -6.189 & 2.782 \\
LNL & 0.046 & 3 & -2.675 & & 1379.823 \\
\hline
\end{tabular}




\begin{tabular}{|c|c|c|c|c|c|}
\hline FARKLNL & 0.023 & 3 & -8.673 & -7.491 & 2.628 \\
\hline LNK & 0.118 & 1 & -3.650 & & 6876.312 \\
\hline FARKLNK & 0.016 & 3 & -3.783 & & 10.968 \\
\hline
\end{tabular}
4.972 şeklindedir.

Tablo 2'de sabit terimli ve trendli birim kök testlerine ait sonuçlar görülmektedir. Değişkenlere seviyelerinde uygulanan FADF birim kök testi, dört değişkenin de durağan olmadığını göstermiştir. Bunun üzerine değişkenlerin birinci farkı alındıktan sonra FADF birim kök testi uygulanmış fakat FARKLNK dışındaki değişkenler için trigonometrik terimlerin anlamsız olduğu tespit edilmiştir. Bu nedenle söz konusu fark serilerine ADF birim kök testi uygulanmış ve değişkenlerin durağan oldukları tespit edilmiştir.

Hem sabit terimli hem de sabit terimli ve trendli seçenekleri için yapılan durağanlık analizi, bütün değişkenlerin seviyesinde durağan olmadığını, birinci farkı alındıktan sonra durağan hale geldiğini göstermektedir. Şekil 1'deki grafiklere bakıldığında, Fourier fonksiyonlarının değişkenlerle uyumlu olduğu görülmektedir.

\section{Şekil 1. Değişkenler ve Fourier Fonksiyonları}
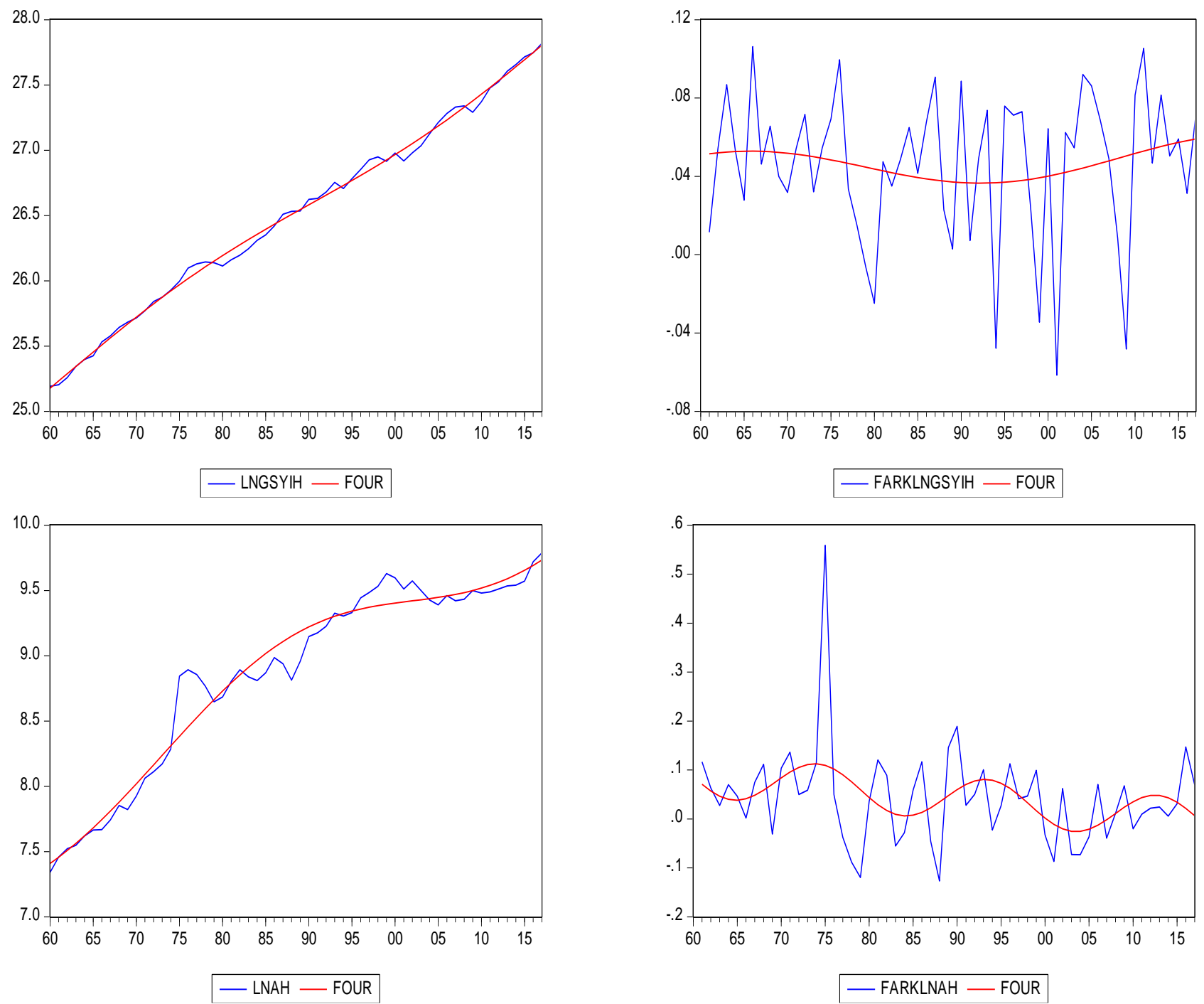

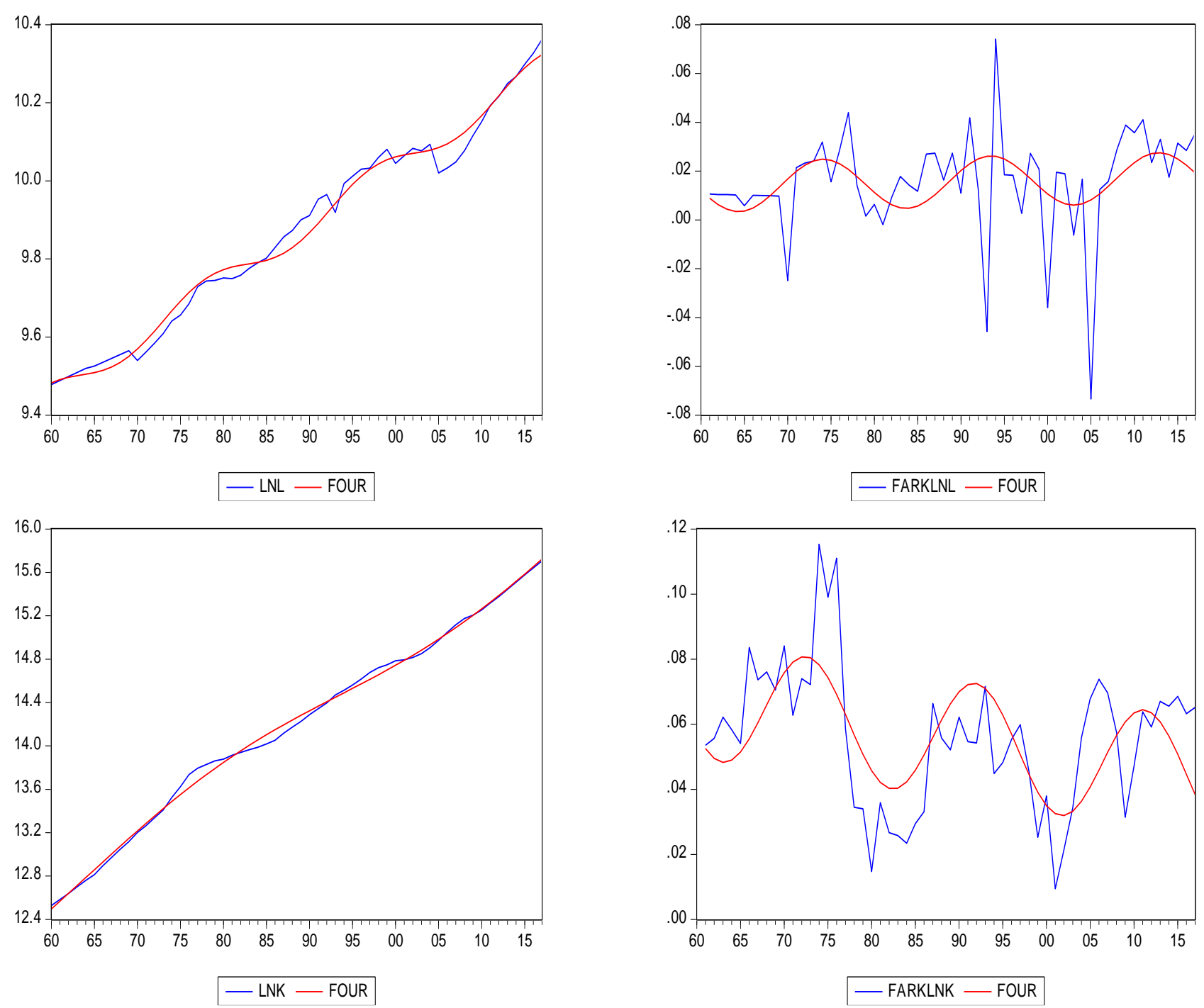

Değişkenler arasındaki uzun dönemli ilişkinin varlığını sınamak amacıyla uygulanan FADL eşbütünleşme testlerine ait sonuçlar Tablo 3 ve Tablo 4'te yer almaktadır:

Tablo 3. FADL Eşbütünleşme Testi Sonuçları (Sabit Terimli)

\begin{tabular}{ccccccc}
\hline $\begin{array}{c}\text { Bağımlı } \\
\text { Değişken }\end{array}$ & \multicolumn{2}{c}{ Bağımsız Değişkenler } & k & Min AIC & $\begin{array}{c}\text { FADL } \\
\text { Eşbütünleşme } \\
\text { Test İstatistiği }\end{array}$ \\
\hline LNGSYIH (3) & LNAH (1) & LNL (1) & LNK (1) & 3 & -3.854 & -3.984 \\
\hline
\end{tabular}

Not: Parantez içerisinde yer alan değerler uygun gecikme sayılarını göstermektedir. \%5 anlamlılık düzeyinde kritik değer -4.16 olarak belirlenmiştir.

Sabit terimli eşbütünleşme testine ait sonuçların yer aldığı Tablo 3'e bakıldığında, FADL test istatistiğinin kritik değerden küçük olduğu görülmektedir. Bu durumda değişkenler arasında uzun dönemli ilişki olmadığını ifade eden temel hipotez reddedilememektedir.

Tablo 4. FADL Eşbütünleşme Testi Sonuçları (Sabit Terimli ve Trendli)

\begin{tabular}{llllllc}
\hline $\begin{array}{c}\text { Bağımlı } \\
\text { Değişken }\end{array}$ & Bağımsız Değişkenler & k & Min AIC & $\begin{array}{c}\text { FADL } \\
\text { Eşbütünleşme } \\
\text { Test İstatistiği }\end{array}$ \\
\hline LNGSYIH (2) & LNAH (3) & LNL (1) & LNK (1) & 1 & -4.037 & 4.353 \\
\hline
\end{tabular}

Not: Parantez içerisinde yer alan değerler uygun gecikme sayılarını göstermektedir. \%5 anlamlılık düzeyinde kritik değer -4.89 olarak belirlenmiştir. 
Sabit terimli ve trendli eşbütünleşme testine ait sonuçların yer aldığ Tablo 4 incelendiğinde, FADL test istatistiğinin kritik değerden küçük olduğu görülmektedir. Bu durum değişkenlerin eşbütünleşik olmadıklarını ifade etmektedir. Son olarak değişkenler arasındaki ilişkinin varlı̆̆ı, Toda ve Yamamoto (1995) tarafindan geliştirilen nedensellik testi ile araştırılmıştır. Test sonuçları Tablo 5 'te görülmektedir.

Tablo 5. Toda-Yamamoto Nedensellik Testi Sonuçları

\begin{tabular}{|c|c|c|c|c|}
\hline Temel Hipotez & AIC & $\mathrm{d}(\max )$ & $\begin{array}{c}\text { Test } \\
\text { İstatistiği }\end{array}$ & $\begin{array}{c}\text { Olasılık } \\
\text { Değeri }\end{array}$ \\
\hline Savunma Harcamaları Ekonomik Büyümenin Nedeni Değildir & 2 & 1 & 2.8577 & 0.2396 \\
\hline Ekonomik Büyüme Savunma Harcamalarının Nedeni Değildir & 2 & 1 & 0.7432 & 0.6896 \\
\hline
\end{tabular}

Tablo 5'te yer alan olasılık değerleri incelendiğinde, her iki model için de bütün anlamlılık düzeylerinde temel hipotezin reddedilemediği görülmektedir. Dolayısıyla değişkenler arasında nedensellik ilișkisi bulunmamaktadır. Elde edilen bulgular, Türkiye'de 1960-2017 yılları arasında savunma harcamalarının ekonomik büyüme üzerinde herhangi bir etkisinin olmadığını göstermektedir.

\section{SONUÇ}

Bu çalışmada, 1960-2017 dönemi için Türkiye'de Benoit hipotezinin geçerliliği Fourier yaklaşımı ile incelenmiştir. Bunun için öncelikle değişkenlere seviyelerinde Fourier ADF birim kök testi uygulanmış ve tamamının durağan olmadığı tespit edilmiştir. Değişkenlerin farkı alındıktan sonra uygulanan birim kök testleri, bütün değişkenlerin birinci farkı alındıktan sonra durağan hale geldiğini göstermiştir. Benoit hipotezinin geçerliliğini sınamak amacıyla Fourier ADL eşbütünleşme testi uygulanmış ve değişkenler arasında uzun dönemli ilişki olmadığı görülmüştür. Toda-Yamamoto nedensellik testinden elde edilen sonuçlar da bu bulguyu desteklemektedir. Ulaşılan sonuçlar, Türkiye'de Benoit hipotezinin geçerli olmadığına işaret etmektedir.

Benoit hipotezinin geçersiz olması, Türkiye'de savunma harcamalarını arttırmanın, ekonomik büyümeyi teşvik etmek amacıyla kullanılabilecek bir araç olarak görülemeyeceği anlamına gelmektedir. Savunma harcamalarında meydana gelen artış, ekonominin geneli üzerinde pozitif dişsallık yaratmamaktadır. Türkiye'de son yıllarda savunma sanayide yüksek teknoloji içeren yerli ürünlere yönelik daha fazla yatırım yapıldığı görülmektedir. Bu yatırımların sürdürülmesi ve ihracata konu olabilecek ürünlerin geliştirilmesiyle, savunma harcamalarının çeşitli sektörlerde pozitif dışsallık yaratarak ekonomik büyümeyi olumlu yönde etkileyebileceği düşünülmektedir. Türkiye'nin bulunduğu coğrafyadaki gerilim ve istikrarsılılılar göz önünde bulundurulduğunda, savunma harcamalarının önümüzdeki yıllarda da artmaya devam edeceğini tahmin etmek zor değildir. Ancak bu harcamaların ekonomik performans üzerinde olumsuz bir etki yaratması beklenmemektedir. 


\section{KAYNAKÇA}

Ajmair, Muhammad ve diğ., (2018) “The Impact of Military Expenditures on Economic Growth of Pakistan”, Applied Economics and Finance 5(2), s. 41-48.

Alptekin, Volkan, (2012) "Benoit Hipotezi: Seçilmiş OECD Ülkeleri Ölçeğinde Panel Veriler Yardımıyla Analizi”, Celal Bayar Üniversitesi Sosyal Bilimler Dergisi 10(2), s. 204-215.

Ateşoğlu, H. Sönmez, (2009) "Defense Spending and Aggregate Output in the United States", Defence and Peace Economics 20(1), s. 21-26.

Becker, Ralf ve diğ., (2006) "A Stationairy Test in the Presence of an Unknown Number of Smooth Breaks", Journal of Time Series Analysis 27(3), s. 381-409.

Banerjee, Piyali ve diğ., (2017) "Fourier ADL Cointegration Test to Approximate Smooth Breaks with New Evidence from Crude Oil Market", Economic Modelling 67, s. 114-124.

Başar, Selim ve Künü, Serkan, (2012) "Savunma Harcamalarının İktisadi Büyümeye Etkisi”, Sosyal Bilimler Enstitüsü Dergisi 10, s. 1-30.

Benoit, Emile, (1978) "Growth and Defense in Developing Countries", Economic Development and Cultural Change 26(2), s. 271-280.

Canbay, Şerif ve Mercan, Derya, (2017) "Savunma Harcamalarının Ekonomik Büyümeye ve Cari İşlemler Dengesine Etkisi: Türkiye Örneği”, Journal of Emerging Economies and Policy 2(2), s. 86-104.

Chen, Qian, (2014) "Causality and Co-integration Relationships between Defense Expenditures and Economic Growth in China", Journal of Chinese Economics 2(2), s. 51-58.

Christopoulos, Dimitris K. ve Leon-Ledesma, Miguel A., (2010) "Smooth Breaks and Non-linear Mean Reversion: PostBretton Woods Real Exchange Rates", Journal of International Money and Finance 29(6), s. 1076-1093.

Cobb, Charles W. ve Douglas, Paul H., (1928) “A Theory of Production”, The American Economic Review 18(1), s. 139165.

Destek, Mehmet Akif, (2016) "NATO Ülkelerinde Askeri Harcamalar ve Ekonomik Büyüme İlişkisi: Yatay Kesit Bağımlılığı Altında Panel Veri Analizi”, Uluslararası Yönetim İktisat ve İşletme Dergisi 12(28), s. 209-223.

Dunne, Paul ve Nikolaidou, Eftychia, (2001) "Military Expenditure and Economic Growth: A Demand and Supply Model for Greece, 1960-96", Defence and Peace Economics 12(1), s. 47-67.

Eğri, Taha ve diğ., (2017) "Seçilmiş Ortadoğu Ülkeleri için Ekonomik Büyüme ve Savunma Harcamaları İlişkisi: Panel Veri Analizi", Siyaset, Ekonomi ve Yönetim Araştırmaları Dergisi 5(5), s. 139-153.

Faini, Riccardo ve diğ., (1984) "Defense Spending, Economic Structure, and Growth: Evidence among Countries and over Time", Economic Development and Cultural Change 32(3), s. 487-498.

Feridun, Mete ve diğ., (2011) "The Impact of Military Spending on Economic Growth: The Case of North Cyprus", Defence and Peace Economics 22(5), s. 555-562.

Gerace, Michael P., (2002) "US Military Expenditures and Economic Growth: Some Evidence from Spectral Methods", Defence and Peace Economics 13(1), s. 1-11.

Gökbunar, Ramazan ve Yanıkkaya, Halit, (2004) "Savunma Harcamalarını Belirleyen Faktörler ve Ekonomik Büyümeye Etkileri”, Ankara Üniversitesi Siyasal Bilgiler Fakültesi Dergisi 59(1), s. 159-179.

Görkem, Hilal ve Işsk, Serkan, (2008) “Türkiye'de Savunma Harcamaları ve Ekonomik Büyüme Arasındaki İlişki (19682006)", Marmara Üniversitesi İktisadi ve İdari Bilimler Dergisi 25(2), s. 405-424.

Halıcığlu, Ferda, (2004) "Defense Spending and Economic Growth in Turkey: An Empirical Application of New Macroeconomic Theory", Review of Middle East Economics and Finance 2(3), s. 193-201.

İpek, Egemen, (2014) "Savunma Harcamalarının Seçilmiş Makroekonomik Değişkenler Üzerine Etkisi: ARDL Sınır Testi Yaklaşımı", Anadolu Üniversitesi Sosyal Bilimler Dergisi 14(3), s. 113-126.

Jalil, Abdul ve diğ., (2016) "Military Expenditures and Economic Growth: Allowing Structural Breaks in Time Series Analysis in the Case of India and Pakistan", Quality and Quantity 50(4), s. 1487-1505.

Karagöl, Erdal ve Palaz, Serap, (2004) "Does Defence Expenditure Deter Economic Growth in Turkey? A Cointegration Analysis", Defence and Peace Economics 15(3), s. 289-298.

Kesgingöz, Hayrettin ve Olcay, Tuğçe, (2016) "Türkiye ve Seçilmiş Ortadoğu Ülkeleri için Benoit Hipotezinin Sinanması: Panel Veri Analizi”, Çankırı Karatekin Üniversitesi İktisadi ve İdari Bilimler Fakültesi Dergisi 6(1), s. 585-607.

Khalid, Masoud Ali ve Razaq, Munadhil Abdul Jabar Abdul, (2015) "The Impact of Military Spending on Economic Growth: Evidence from the US Economy”, Research Journal of Finance and Accounting 6(7), s. 183-190.

Korkmaz, Özge ve Bilgin, Tuba, (2017) "Askeri Harcamalar ile Ekonomik Büyüme Arasındaki İlişki: Türkiye ve Amerika Birleşik Devletleri’nin Karşılaştırmalı Analizi”, Uluslararası İktisadi ve İdari İncelemeler Dergisi 9(18), s. 289-316.

Korkmaz, Suna, (2015) "The Effect of Military Spending on Economic Growth and Unemployment in Mediterranean Countries", International Journal of Economics and Financial Issues 5(1), s. 273-280.

Kovacevic, Tomislav ve Smiljanic, Drazen, (2017) "Causality Analysis Between GDP, Defence Expenditure and the Number of Armed Forces Personnel: the Case of Croatia”, Ekonomski Pregled 68(4), s. 413-431.

Lee, Chien-Chiang ve Chen, Sheng-Tung, (2007) "Non-linearity in the Defence Expenditure-Economic Growth Relationship in Taiwan", Defence and Peace Economics 18(6), s. 537-555. 
Manamperi, Nimantha, (2016) "Does Military Expenditure Hinder Economic Growth? Evidence from Greece and Turkey", Journal of Policy Modeling 38(6), s. 1171-1193.

Pan, Chia-I ve diğ., (2015) "Military Spending and Economic Growth in the Middle East Countries: Bootstrap Panel Causality Test", Defence and Peace Economics 26(4), s. 443-456.

Paparas, Dimitrios ve diğ., (2016) "Military Spending and Economic Growth in Greece and the Arms Race between Greece and Turkey", Journal of Economics Library 3(1), s. 38-56.

Pradhan, Rudra Prakash, (2010) "Defense Spending and Economic Growth in China, India, Nepal and Pakistan: Evidence from Cointegrated Panel Analysis", International Journal of Economics and Finance 2(4), s. 65-74.

Soyyiğit Kaya, Semanur, (2013) “Türkiye’de Savunma Harcamalarının İktisadi Etkileri Üzerine Nedensellik Analizi (1970-2010)", Trakya Üniversitesi Sosyal Bilimler Dergisi 15(2), s. 17-38.

Şit, Mustafa, (2018) "Macroeconomic Effects of Defense Expenditures in Turkey", The Journal of Defense Sciences 17(2), s. 93-114.

Tiwari, Aviral Kumar ve Shahbaz, Muhammad, (2013) "Does Defence Spending Stimulate Economic Growth in India? A Revisit", Defence and Peace Economics 24(4), s. 371-395.

Toda, Hiro Y. ve Yamamoto, Taku, (1995) "Statistical inference in vector autoregressions with possibly integrated processes", Journal of Econometrics 66(1-2), s. 225-250.

Topal, Mehmet Hanefi, (2018) "Türkiye'de Askeri Harcamalar ile Ekonomik Büyüme Arasındaki İlişkinin Bir Analizi (1960-2016)", Maliye Dergisi 174, s. 175-202.

Turan, Taner ve diğ., (2018) “Askeri Harcamalar ve Ekonomik Büyüme İlişkisi: Panel Eşbütünleşme ve Nedensellik Analizi”, Maliye Dergisi 175, s. 140-153.

Wijeweera, Albert ve Webb, Matthew J., (2009) "Military Spending and Economic Growth in Sri Lanka: A Time Series Analysis", Defence and Peace Economics 20(6), s. 499-508.

Yılancı, Veli ve Özcan, Burcu, (2010) "Yapısal Kırılmalar Altında Türkiye İçin Savunma Harcamaları ile GSMH Arasındaki İlişkinin Analizi”, Cumhuriyet Üniversitesi İktisadi ve İdari Bilimler Dergisi 11(1), s. 21-33.

Yılancı, Veli, (2017) "Petrol Fiyatları ile Ekonomik Büyüme Arasındaki İlişkinin İncelenmesi: Fourier Yaklaşımı", Ekonometri ve İstatistik Dergisi 27(2), s. 51-67.

Yıldırım, Jülide, (2005) "Military Expenditure and Economic Growth in Middle Eastern Countries: A Dynamic Panel Data Analysis", Defence and Peace Economics 16(4), s. 283-295.

Yıldız, Barış ve Akbulut Yıldız, Gizem, (2019) “Ortadoğu Ülkelerinde Askeri Harcamalar ile Ekonomik Büyüme Arasındaki İlişki: Bootstrap Panel Granger Nedensellik Analizi”, Sayıştay Dergisi 112, s. 53-74. 